\title{
Phrenology and the Rwandan Genocide
}

\author{
Frenologia e o Genocídio de Ruanda
}

Charles André

\begin{abstract}
Belgian colonizers used phrenology to create an irreducible division between the two major groups living for centuries in Rwanda-Urundi. This formed the basis for the implementation of systematic efforts to subdue the large Hutu population. Both the Hutus and the smaller, and initially privileged, Tutsi group soon incorporated the racist discourse, which was pivotal to the gradual increase in violence before and after Rwandan independence in 1962. The Rwandan genocide in 1994 culminated in the horrible pinnacle of this process, involving recurrent episodes of slaughtering. Doctors should not underestimate the racist potential of pseudoscientific misconceptions.
\end{abstract}

Keywords: genocide; history, 20th century; phrenology; racism.

\section{RESUMO}

Os colonizadores belgas usaram a frenologia para criar uma divisão irredutível entre os dois maiores grupos populacionais vivendo há séculos em Ruanda-Urundi. Isso criou as bases para a implementação de esforços sistemáticos para subjugar a grande população Hutu. Tanto os Hutu quanto o grupo menor e inicialmente privilegiado dos Tutsi logo incorporaram o discurso racista, que foi crucial no aumento gradual da violência antes e após a independência de Ruanda em 1962. O genocídio de 1994 constituiu o terrível ápice deste processo envolvendo massacres repetidos. Os médicos não devem subestimar o potencial racista e discriminatório de falsas concepções pseudocientíficas.

Palavras-chave: genocídio; história do século 20; frenologia; racismo.

The role of phrenology in the Nazi racist segregation of Jewish people during the Holocaust is relatively well discussed $^{1}$. Its pivotal role in the genesis of the Rwandan genocide at the gates of the $21^{\text {st }}$ century is less known and is the subject of this short review.

\section{PHRENOLOGY AND RACISM}

In late $18^{\text {th }}$ century, mind and soul were considered to determine human behaviour, and this was judged mainly according to religious and spiritual criteria. Creationism was considered indisputable and lent support to racist theories, as different ethnic groups were seen as diverse races as conceived by God. Creationism would only be challenged in the second half of the $19^{\text {th }}$ century after the publication of Darwin's On the Origin of the Species (1859).

Dr. Franz Joseph Gall (1758-1828) was a pioneer in the development of theories connecting human behaviour and cerebral function. According to him, mental and spiritual characteristics of the individual directly reflected differences in brain structure, especially the cortical areas. In addition, these differences could be evaluated objectively by examining the corresponding areas of the cranial vault.

Gall and his early followers in Germany and Austria did not mention racial differences as their subject of interest ${ }^{2}$. However, since the early development of organology (later called physiology of the brain), social discrimination and segregation according to craniological criteria - even in children - were held up as one of its most important aspects. From 1805 on, Gall lectured on the new system in Germany, Denmark, Switzerland and France, where he finally settled in 1807. During this lecturing tour, he visited houses of correction and prisons, and "gave the most convincing proofs of his ability to discover, at first sight, such malefactors, thieves, and men of particular talents as were amongst the convicts and prisoners"3.

Anumber ofthepioneer'sideaslentsupportand prestigetoconventional prejudices. Gall considered some Asian groups disposed to "theft and ruse", and other groups from India were described as "cruel, superstitious, and stupid"4. Johann G. Spurzheim (17761832), Gall's disciple and later a distinguished lecturer on phrenology, affirmed the "destructiveness" of the Caribs". 
Other early proponents of phrenology expressed unequivocal racist ideas ${ }^{4}$. In France, an incomplete list includes Dr. François J.V. Broussais (1772-1838), who thought some people would "never become civilized" ${ }^{4,6}$, his son Dr. Casimir A-Me. Broussais (1803-1847), Dr. Pierre H. Gaubert (1796-1839), who ranked talents by racial criteria, Joseph Vimont (1795-1857), and the naval officer and explorer Jules Dumont D’Urville (1790-1842) 4 . Spurzheim's stepson, the painter Hyppolyte Bruyères (1801-1855), believed in a "vicious cerebral conformation" of certain races and their animal-like nature and amorality, and commented on the "immense differences" between the "miserable and frightful savage of New Holland" and the "superb and virtuous Germanic race". Dr. Jean B.I. Bourdon (1796-1861) thought that it was a European's destiny to educate or subjugate other less intelligent races, and described the "Hottentots" (Khoikhoi) as hopeless, "stupid... intermediates between humans and apes". The prison physician, Hubert Lauvergne (1797-1859), claimed an "immutability of the Jewish type" and saw the Makua of southeast Africa "at the bottom of the human chain...hardly superior to animal instincts". He saw "more resemblance between the heads of Negroes and of great apes than between Negroes and Europeans"4.

In Britain, the founder of the Edinburgh Phrenological Society and lawyer, George Combe (1788-1858), suspected that the "development of the brain sets limits to the spontaneous development of civilization in different races" and the Phrenological journal warned against intermarriage between British soldiers and officers and the primitive races in the British Empire 4 .

Despite early skepticism regarding phrenology in the many scientific circles of the $19^{\text {th }}$ century $^{3}$, it survived well into the $20^{\text {th }}$ century, in the Americas as well as in European countries and their Asian and African colonies. Specifically, early works focused on miscegenation, and studies by Eugene Fischer (1874-1967) in German South West Africa (today's Namibia) involved physical measurements and led to prohibition of mixed-race marriages in all German colonies in 1912 1,7. After losing its African colonies at the start of World War I, similar studies on mixed populations were held in Germany and led to sterilization of German Blacks, also called the "Rhineland Bastards". Similar methods were later used for physical-anthropological characterization of Jews, and the justification of racial purification and the Holocaust ${ }^{1,8}$.

\section{THE RWANDAN MASS MURDER AND THE BELGIAN ROLE}

Three major groups lived in the Rwandan region for many centuries. A unified population was created, after Tutsi settlers from eastern regions (Congo) entered Rwanda from the $14^{\text {th }}$ century on ${ }^{9}$. Local cattle holders were incorporated as Tutsis and farmers as Hutus. Both groups had their own rich elites. There was a third, small (1\%) group, the Twa, thought to be remnants of the Pygmies living in the area. For a long time, the Tutsis tended to be wealthier and constituted a sort of elite. A complex feudal regimen, in which most lords were Tutsi herders, was gradually instituted during the $19^{\text {th }}$ century, and power was centralized under a king named Rwabugiri (1865-1895). Although this contributed to the crystallization of different social roles for Tutsis and Hutus, wealthy members of the latter group were also part of the elite and had strong feelings of superiority over Hutu peasants ${ }^{9}$. Sometimes they married Tutsi women, and their children became Tutsis. In addition, the vast majority of Tutsis were exploited commoners, just like the Hutu peasants.

Belgium first occupied the Rwanda-Urundi colony in $1912^{9}$ and more firmly during World War I as retaliation for the German invasion in 1914. The League of Nations recognized the region as a Belgian colony in 1919. At the time of the European colonization, a myth of ancient Ethiopian ancestry and racial superiority of the Tutsis was introduced $^{9}$. In 1864, the British explorer John H. Speke (1827-1884) wrote that the Hutus were a "primitive race," "the true curly-headed, flab-nosed, pouched-mouthed Negro", while the Tutsis "descended from the best blood of Abyssinia" and were, therefore, far superior ${ }^{10}$ (Speke, 1864). Belgian settlers disseminated the myth ${ }^{9,11}$. An influential 1931 documentary, The Congo I Knew, made by Armand Denis (1896-1971), probably contributed ${ }^{12}$. All this led to increasing tension and discrimination against the Hutu and Twa populations.

From 1933 on, everyone was issued a racial identity card stating his or her original ethnic group ${ }^{11,13}$ (Figure 1). Belgian specialists came to the region to classify people according to stereotypical anatomic-anthropological features ${ }^{12}$ (Figure 2). Craniofacial and body measurements were taken and a number of distinguishing features were considered for ethnic classification of the population. Tutsis had a taller stature (probably related to better nutrition). The head format, color of the eyes and skin (lighter) and the size of the noses (longer and narrower) were important features, which, as a group, was considered to resemble white Europeans (Figures 2 and 3).

This classification system had lasting consequences for all descendants. It was deemed essential by the overtly racist Hutu authorities after independence ${ }^{13}$. Despite renewed discussion and an apparent willingness to discuss its termination from 1990 on, the classification system was still in use, and became a central instrument to rapidly identify and kill Tutsis during the 1994 genocide. Ethnic classification in identity cards was only abolished in $1997^{13}$ (Figure 1).

The Belgians never took a controlling role in the administration of the colony. They chose the Tutsi group as superior, and strongly restricted the access of Hutus 
(comprising $85-90 \%$ of the population) to higher education, land ownership and administrative posts ${ }^{9,11,16}$. They also helped subject Hutus to forced labour under Tutsi supervision. They created new institutions like the Native Tribunals (1936) headed by Tutsi chiefs, gradually increasing their power, ${ }^{9,11}$.
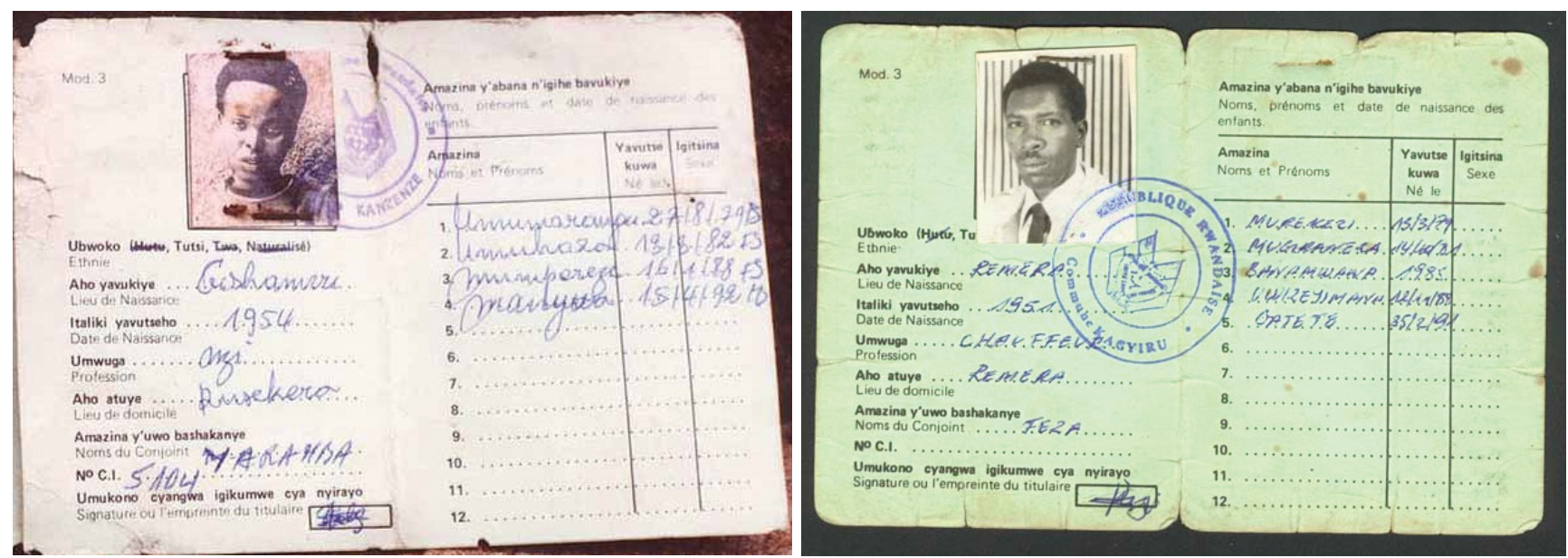

Figure 1. Identity cards of two Rwandan Tutsis. Delivered in the 1950s by Belgian authorities, they show date and city of birth, profession, name of spouse, and children's birthdays as late as the 1990s.14.15
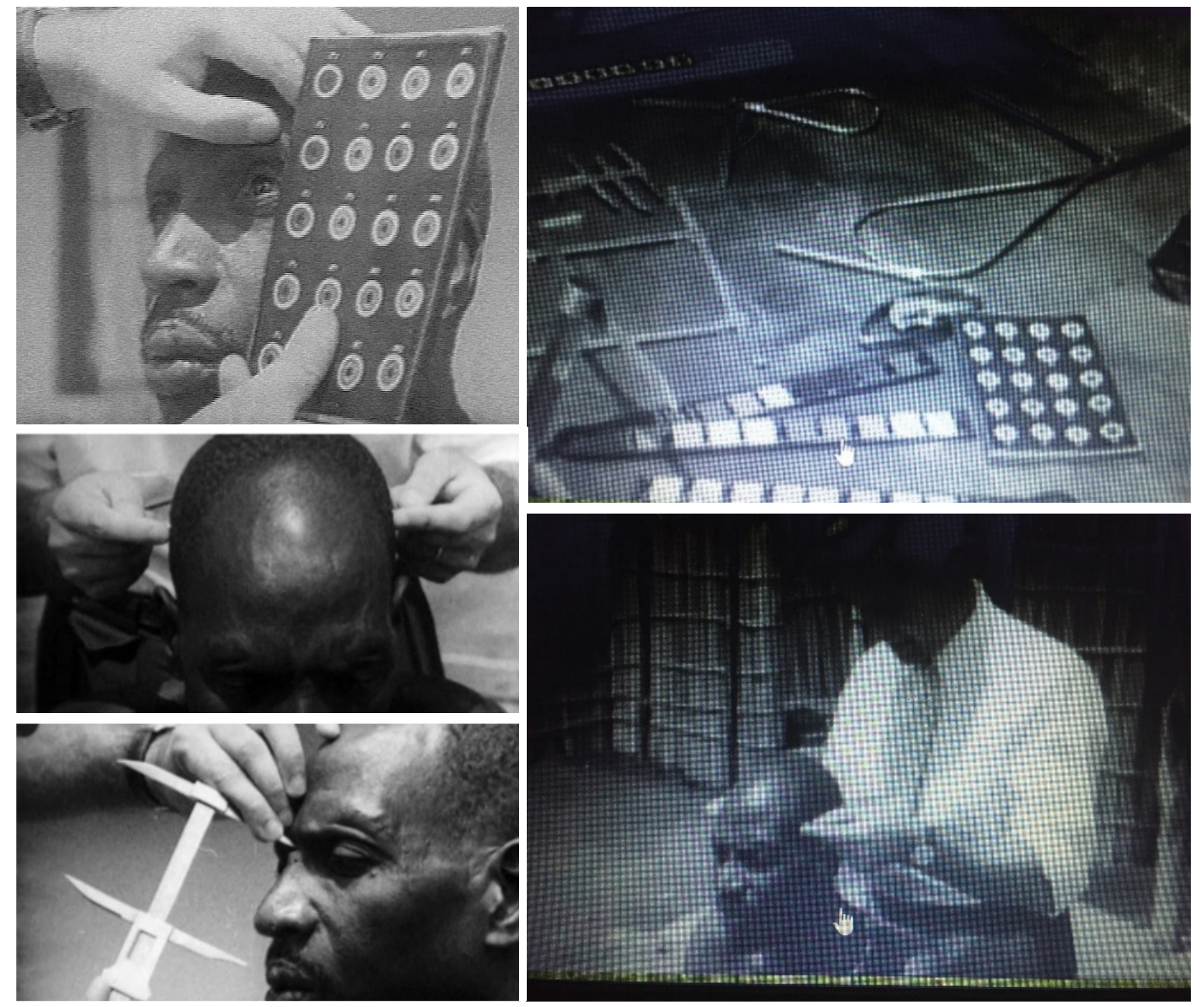

Figure 2. Craniology as deemed by Belgian specialists in Rwanda in the 1930s. Belgian specialists came to evaluate people, using typical instruments. Still images retrieved from the film "All Watched Over by Machines of Loving Grace 3 of 3 Monkey in the Machine, 2011"12 


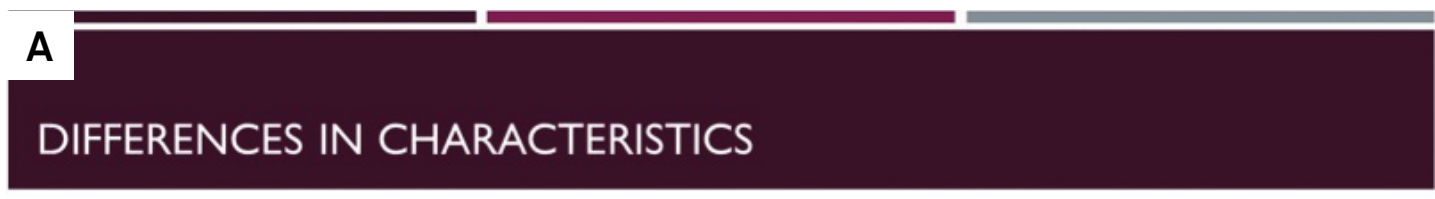

Hutu
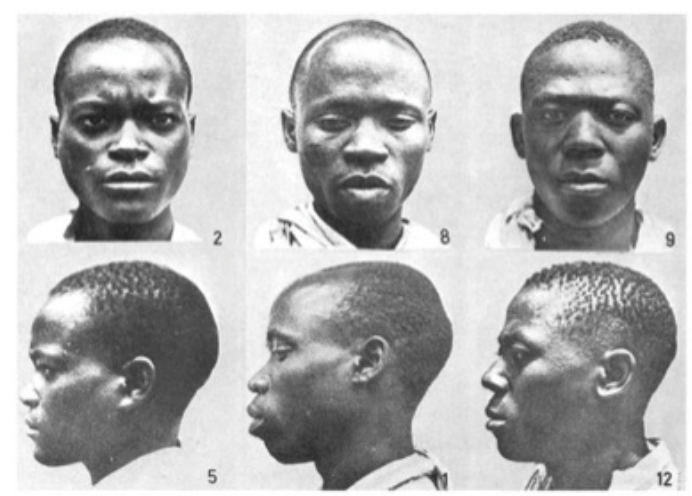

Tutsi
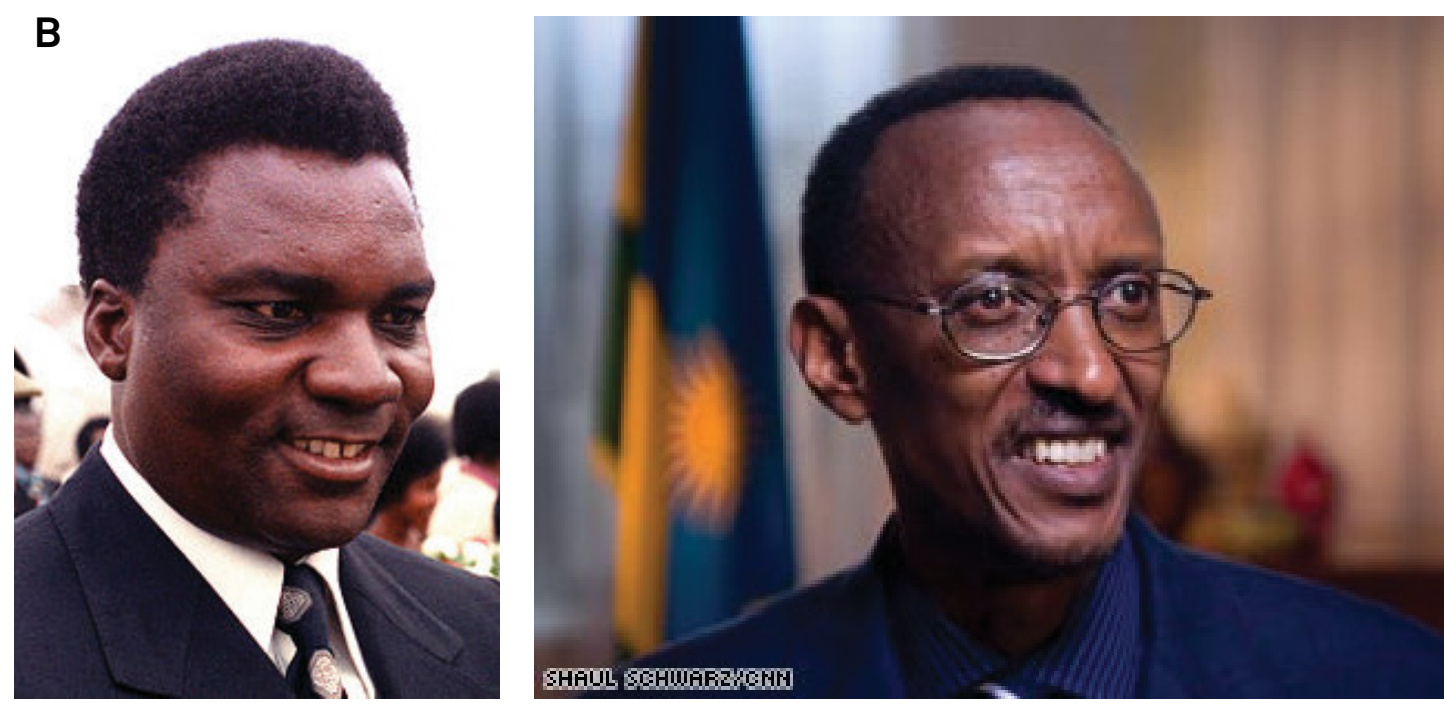

Figure 3. A. Charts used to help differentiate Hutu and Tutsi people ${ }^{17}$. B. Symbolic examples of Rwandans of Hutu and Tutsi background: president Juvénal Habyarimana (1937-1994) who ruled from 1973 until his death in 1994 ${ }^{18}$; and President Paul Kagame (n.1954), current president since $2000^{28}$

\section{THE HUTU REACTION AND THE GENOCIDE}

Before independence, Belgian rulers attempted to approach the increasingly angry and resentful Hutu majority. The Belgians feared the increasingly dissatisfied Tutsis, who now overtly discussed and longed for independence. They were trying to prolong their colonial rule, now favoring the Hutus and reducing the power of the Tutsis. The myth of the foreign ancestry of the Tutsis was now used in reverse to increase resentments against this group ${ }^{9,11,20}$.

In the wake of separatist movements throughout Africa, the Hutu reaction, stimulated by the Belgians, and included a 1957 manifesto retaining group classifications, was to prepare for political battle incorporating ethnic justification for revenge ${ }^{13}$; resulting in violent outbreaks and slaughtering in 1957, 1959-61, and 1962. In 1959, the Hutu forces overthrew the Tutsi rule. The region became officially independent in 1962, split into two new countries - Rwanda (a republic) and Burundi (a monarchy) ${ }^{21}$.

After independence, violence gradually escalated ${ }^{11,22}$. Tutsi forces invaded Rwanda from Burundi in 1963. Tutsis were massacred in 1973 after a coup and establishment of a dictatorship. Hundreds of thousands of Tutsis were expelled from the country ${ }^{25}$. Tutsi refugees created the Rwandan Patriotic Front in 1986. There was a military invasion and transient deposition of the dictator Juvénal Habyarimana (1937-1994) in 1990. In 1990, the pamphlet Hutu 10 Commandments, with explicit reference to ethnic killing was published ${ }^{24}$. Also, Interahamwe ("those who attack together"), a violent Hutu youth militia, was created, and there was a gradual increase in violence stimulated by the official radio station (Radio-Télévision Libre des Mille Collines) $^{25}$. 
In 1993, Habyarimana and the Rwandan Patriotic Front signed a peace treaty allowing the incorporation of the latter into the national army and the return of refugees to Rwanda. The fragile peace was broken on April 6, 1994, when the president was killed. A rocket struck his plane near the capital airport, and Tutsis were immediately held responsible. What followed is probably beyond adequate description. The death toll is calculated to have been between 800,000 and two million $^{11,15,16,21}$. Some two million Rwandans fled to neighbouring countries. Perhaps a quarter million women were raped and either killed or infected with HIV. Although, obviously, the majority of victims of the slaughter were Tutsis, they did not have just a passive role in the massacre. An unspecified, but large, number (probably hundreds of thousands) of Hutus were also killed with the same savagery, by the Rwandan Patriotic Front troops during the relatively short time (April-July 1994) of mass conflict and before a provisional government was established ${ }^{11,26}$.

\section{CONCLUSIONS}

Of course, the Rwandan genocide cannot be attributed directly to Belgium or Belgian rulers. Prejudice and social discrimination were widespread in Rwandan society for at least a century before the occupation. The political and social gap between the elite and the vast poor rural population was enormous. Complex and competing interests involving neighbouring countries (Burundi, Zaire/Congo), France and the USA contributed to the extension of the massacre ${ }^{11,17,20,21}$. The United Nations peacekeeping troops were easily neutralized after 10 Belgian peacekeepers were tortured and killed.

However, the importance of explicit racial discrimination of the Rwandan population, introduced by Belgian colonizers, must not be underestimated as a driving force for ethnic stratification and hatred. Before the arrival of the Belgians, Tutsi and Hutu people did not see each other as different races, but both sides soon incorporated the racial question in their discourse and justification for violence.

Scientific and medical misconceptions, including phrenology, can be used to justify racist and other discriminatory politics ${ }^{13}$. The British Phrenological Association only ended in 1967, and there are European sites and associations still promoting phrenology today ${ }^{27,28}$. Concepts, such as savage or primitive characteristics, are openly discussed there and simple formulas are offered to detect these primitive traits.

Modern society is prone to stigmatization, discrimination and simplification. In the Internet era, people seem eager to resolve complex problems using wrong pseudoscientific concepts. Unfortunately, in this dysfunctional world, phrenological stereotypes can be used to find new avenues for discrimination including racism.

\section{References}

1. Becker H. Auschwitz to Rwanda: the link between science, colonialism and genocide. 2017 [cited 2017 Aug 23]. Available from: http://theconversation.com/auschwitz-to-rwanda-the-linkbetween-science-colonialism-and-genocide-71730

2. Gall F. Letter from Dr. F.J. Gall, to Joseph Fr[eiherr] von Retzer, upon the Functions of the Brain, in Man and Animals. Der neueTeutscheMerkur. 1798[cited 2017 Aug 23].;3:311332. Available from: http://www.historyofphrenology.org.uk/texts/retzer.htm

3. Wyhe J. The authority of human nature: the Schädellehre of Franz Joseph Gall. Br J Hist Sci 2002;35(1):17-42.

4. Staum MM. French scholars on society, race, and empire, 1815-1848. Montreal: McGill-Queens University Press; 2003. Chapter 3: The ambivalence of phrenology, p. 49-84.

5. Spurzheim. Lectures on phrenology. Lancet. 1825 May;4(86):204-10.

6. Broussais, FJV. Lectures on phrenology, delivered in 1836 in the University of Paris. [S.L.]: G. Churchill, 1836.

7. Peace Pledge Union Information. Genocide. Talking about genocide: Namibia 1904. London: Peace Pledge Union; [s.d.] [cited 2017 Aug 23]. Available from: http://www.ppu.org.uk/genocide/g_namibia1.html

8. Esther M.Zimmer Lederberg Memorial Website. Eugenics: Eugen Fischer. [S.I.]: The Esthger M.Zimmer Lederberg Trust; 2017 [cited 2017 Aug 23]. Available from: http://www.estherlederberg.com/ Eugenics\%20(Anecdotes)/Eugen\%20Fischer.html

9. Jefremovas V. Contested identities: power and the fictions of ethnicity, ethnography and history in Rwanda. Anthropologica. 1997;39(1/2):91-104.

10. Speke JH. Journal of the Discovery of the Source of the Nile. New York: Harper \& Brothers; 1864 [cited 2017 Sep 10]. Available from: https://ia902708.us.archive.org/3/items/ journaldiscover02spekgoog/journaldiscover02spekgoog.pdf
11. Gourevitch P. We wish to inform you that tomorrow we will be killed with our families: stories from Rwanda. New York: Farrar, Straus \& Giroux; 1998.

12. Curtis A. All watched over by machines of loving grace 3 of 3 monkey in the machine. 2011 [cited 2017 Aug 25]. Available from: https:// www.youtube.com/watch?v=AXOLQzkaZ2g

13. Fussell J. Group classification on national ID cards as a factor in genocide and ethnic cleansing. 2001 (cited 2017 Sep 10]. Available from: http://www.preventgenocide.org/prevent/removingfacilitating-factors/IDcards/

14. Differences in characteristics. [s.d.] [cited 2017 Sep 10]. Available from: http://theedge.com.hk/wp-content/uploads/2016/08/Tutsiand-Hutu-people.png

15. Juvénal Habyarimana. Wikipedia. [s.d.] [cited 2018 Apr 02]. Available from: https://en.wikipedia.org/wiki/Juv\%C3\%A9nal_Habyarimana

16. Washington College of Low. GroupOne: The Hutus and Tutsis. Washington, DC: Washington College of Law; 2017 [cited 2017 Sep 10]. Avaiable from: https://www.wcl.american.edu/humright/center/ rwanda/jigsaw1.pdf

17. Shifman K. From child refugee to Rwanda's reconciliation president. In: Scream Bloody Murder. 2008. [s.d.] [cited 2018 Apr 02]. Available from: http://edition.cnn.com/2008/WORLD/africa/11/13/sbm. rwanda.kagame/index.html

18. Juvénal Habyarimana. Wikipedia. [s.d.] [cited 2018 Apr 02]. Available from: https://en.wikipedia.org/wiki/Juv\%C3\%A9nal_Habyarimana

19. Shifman K. From child refugee to Rwanda's reconciliation president. In: Scream Bloody Murder. 2008. [s.d.] [cited 2018 Apr 02]. Available from: http://edition.cnn.com/2008/WORLD/africa/11/13/sbm. rwanda.kagame/index.html 
20. Bonneau S. The Rwandan Myth. [S. L.]: Sungrammata. 2014 [cited 2017 Aug 25]. Available from: http://sungrammata.com/the-rwandan-myth/

21. Pateman R, Elliot M (Eds.). Cultures of the world: Belgium. 2nd ed. New York: Marshall, Cavendish Benchmark; 2006.

22. Fornace K. The Rwandan genocide. Beyond intractability. Boulder: University of Colorado; 2009 [cited 2017 Aug 25]. Available

from: https://www.beyondintractability.org/casestudy/fornacerwandan\#sthash.gQtFwsHM.RfG8i73s.dpbs

23. deWaal A. Rwanda. (Letter). The Lancet 1995;345:322.

24. Kangura No. 6. Appeal to Bahutu conscience: with the Hutu ten commandments. [cited 2017 Aug 11]; Available from: https:// pt.scribd.com/document/327642633/Hutu-Propaganda
25. Human Rights Watch. Leave none to tell the story: genocide in Rwanda, 1 March 1999. [S. d.] [cited 2017 Sep 10]. Available from: http://www.refworld.org/docid/45d425512.html

26. Davenport C, Stam AC. What really happened in Rwanda? Miller-MCCune. 2009 Oct. [cited 2017 Oct 19]. Available from: http://politics.virginia.edu/wp-content/uploads/2015/11/StamRwanda-VISC.pdf

27. Wyhe J. The history of phrenology of the Web. 2011 [cited 2018 Apr 02]. Available from: http://www.phrenology.org/

28. Wikiwand. Frenology. [s.d.] [cited 2018 Apr 02]. Available from: http:// www.wikiwand.com/id/Frenologi 